Arhe XVII, 34/2020

UDK 16 Heidegger M.

$13: 81$ '36

DOI https://doi.org/10.19090/arhe.2020.34.131-157

Originalni naučni rad

Original Scientific Article

BOJAN SRETOVIĆ ${ }^{1}$

Univerzitet u Novom Sadu, Filozofski fakultet

\title{
MESTO SPEKULATIVNE GRAMATIKE U RANOJ HAJDEGEROVOJ FILOZOFIJI
}

Sažetak: Hajdegerovi često zapostavljeni rani radovi o logici sadrže naznake onoga što će kasnije postati poznato kao njegov „okret ka jeziku“. Podstaknut Huserlovom tvrdnjom, iznesenom u „Logičkim istraživanjima“, da postojanje apriornih zakona koji određuju moguće forme značenja govori u prilog osnovanosti stare ideje univerzalne gramatike, Hajdeger će ponuditi fenomenološko čitanje spisa Dunsa Skota De modis significandi. Pored fenomenologije kao dominantne struje, u svom habilitacionom radu Hajdeger će na jednom mestu pokušati da izmiri zahteve neosholastike, neokantovstva i filozofije života. Neokantovsko bavljenje problemom graničnih fenomena suda, poput impersonalija, pitanja i negativnih sudova, imaće poseban značaj za Hajdegera. Iako će Laskova metagramatička teorija predikacije ustupiti mesto Huserlovoj ideji čiste gramatike, upliv Laskove misli na Hajdegerovo rano delo biće nemerljiv. Njegovo razmatranje uloge refleksivnih kategorija ukazaće Hajdegeru na skrivene strukture živog jezika iz kojih filozofski govor mora da crpe.

Ključne reči: Hajdeger, spekulativna gramatika, Huserl, Lask, logika

Hajdegerovi rani filozofski radovi svakog tumača njegove filozofije stavljaju pred nerešiv zadatak - da li se prema njima odnositi kao nespretnim pokušajima krčenja sopstvenog filozofskog puta ili u njima tražiti „rodno mesto“ filozofije? Privlačnosti ove dileme u velikoj meri doprineće i sam Hajdeger koji će, uprkos svesnom isticanju

\footnotetext{
${ }^{1}$ E-mail adresa autora: sretb3@gmail.com
} 
skromnosti svojih ranih lutanja na planu filozofije, u jednoj svojoj kasnoj izjavi svoj razvojni put opisati Helderlinovim rečima „kako si započeo, takav ćeš ostati“ (Hajdeger 2007: 89). Pre nego što bi se, s punim pravom, pribeglo solomonskom rešenju i istini dodelilo mesto između dve krajnosti, u ovom se radu svesno želi više simpatije pokazati za ovo drugo mišljenje, koje pravi početak Hajdegerove filozofije smešta znatno ranije, a motiv za takvo nešto obrazložiti pretpostavkom da se uprkos nesrazmerno sve većem interesovanju za Hajdegerova dela, nedovoljno pažnje poklanja njegovim počecima. Razlog što je rani Hajdegerov opus zanemaren može se tražiti i u činjenici da su njegova poratna predavanja u trenutku kada se njegova misao već osamostalila, kasnije od strane njegovih studenata smatrana skrivenim izvorom njegove filozofije. Izjave poput one Hane Arent da tajna Hajdegerovog „Bivstvovanja i vremena“ leži u njegovim ranim predavanjima čija će se slava tiho pronositi širom intelektualnog sveta, u prilog čemu govori i mišljenje Hansa-Georga Gadamera, da Hajdegerovo glavno delo predstavlja ishitrenu reviziju njegovih ranih predavanja koje u vreme kada je pisano već gubi korak sa samom njegovom misli, samo su deo korpusa mišljenja njegovih sledbenika koji su za razliku od šire javnosti magnum opus svoga učitelja umesto sa oduševljenjem dočekali sa primetnim razočaranjem. U krugu Hajdegerovih učenika preovladao je stav da je živa misao izneverena zarad sholastičke hladnoće formalnih stavova. Čini se, pri tom, da se neretko zaboravlja na sličnost koju je delo „Bivstvovanje i vreme“ u svojoj formi delilo sa Huserlovim „Logičkim istraživanjima“, čija se magičnost za Hajdegera protezala i na fizički izgled samog trotomnog izdanja, o čemu će on kasnije posvedočiti u jednom prilogu naslovljenom „Moj put u fenomenologiju“ (Hajdeger 1998: 82).

Činjenica da je njegovo zamašno delo izdato od strane istog izdavača kao i Huserlova „Logička istraživanja“ za Hajdegera očito nije nosila samo puku sentimentalnu vrednost, već je trebalo da predstavlja i izvesni kontinuitet, znak istrajavanja na onom putu čije će smernice postaviti Huserlovo ključno delo. Ali „Bivstvovanje i vreme“, kao što je poznato, uprkos tome što je nosilo Hajdegerovu posvetu svome mentoru, svedoči pre o njegovom otvorenom raskidu sa Huserlovom transcendentalnom fenomenologijom. Period Hajdegerovog postepenog 
udaljavanja od ortodoksne fenomenološke struje protegnuće se na jednu punu deceniju i biće propraćen, ne bez razloga, „postom“ na planu objavljivanja dela. Iako bi se kao povod ovoj ćutnji mogla navesti i ona vrsta obazrivosti koja prati svaki savesni rad na polju istraživanja, inače do te mere izražene kod Hajdegerovog učitelja da se graničila sa fobijom od objavljivanja, jaz koji razdvaja Hajdegerov veliki filozofski proglas i njegov habilitacioni rad kojim će kulminirati njegova rana faza mišljenja, govori samo u prilog ovoj ćutnji. Različita po obimu, dometu i značaju, kao i recepciji koja je usledila, oba ova dela imaju i nešto zajedničko, naime, oba su posvećena Hajdegerovim mentorima, Hajnrihu Rikertu i Edmundu Huserlu, i pisana su u relativno kratkom roku, kao proizvod nužde jer su bila uslov napredovanja u akademskoj karijeri. Ono što, međutim, dodatno povezuje ova dva dijametralno različita spisa i dve važne prekretnice u Hajdegerovom akademskom i filozofskom radu jeste tema jezika. Dve godine pre pojavljivanja „Bivstvovanja i vremena“, u „Prolegomenama za povest pojma vremena“, problem jezika će po prvi put biti eksplicitno postavljen za razliku od dotadašnje njegove samo uzgredne tematizacije. Budući da je ovo predavanje poslužilo kao jedna vrsta predloška za Hajdegerovo glavno delo, analiza pojma jezika koja je u njemu data biće velikim delom preneta u „Bivstvovanje i vreme“, izuzmemo li izvesne strukturalne izmene. Još u „Pojmu vremena“ iz 1924. godine Hajdeger će istaći da ukoliko želimo da se približimo fenomenu jezika kao primarnom načinu bivstvovanja javnosti, moramo ga u celoj njegovoj fenomenološkoj realnosti ,uzeti nazad u tubivstvovanje, kao način bivstvovanja tubivstvovanja“" (Heidegger 2004: 27). ${ }^{2}$ U razmatranju jezika moralo se zato poći od struktura tubivstvovanja, čime će problem jezika svoju eksplikaciju u „Bivstvovanju i vremenu“ pronaći u okviru egzistencijalne analitike tubivstvovanja. Time što tubivstvovanje čini očitim u njegovoj otkrivenosti, jezik će, za Hajdegera, biti bivstvena mogućnost samog tubivstvovanja, odnosno, biće ukorenjen u egzistencijalnom ustrojstvu dokučenosti tubivstvovanja.

\footnotetext{
${ }^{2}$ Ukoliko nije drugačije naznačeno, svi prevodi izvornog teksta B. S.
} 
Hajdegerovo zanimanje za problem jezika primetno je još u njegovim ranim radovima posvećenim problemu logike. U jednom kasnom razgovoru sa japanskim kolegom Hajdeger će se saglasiti da se u naslovu njegovog habilitacionog spisa „Učenje Dunsa Skota o kategorijama i značenju“ pod teorijom značenja već krilo pitanje o jeziku (Hajdeger 2007: 88). Već u samom habilitacionom radu Hajdeger će na jednom mestu istaći da je utvrđivanje problema i zadatka učenja o značenju trebalo, pored ostalog, da pomogne u donošenju suda o tome „kako i u kojoj meri filozofija mora, i može uopšte, imati posla sa „jezikom““، (Heidegger 1978: 303). Problem odnosa logike i jezika koji će zaokupljati pažnju mladog Hajdegera deo je žive polemike koju će on samo zateći, susrevši se sa njom na samim svojim počecima, u delima Huserla i njegovog učitelja Franca Brentana. Ključ u rešenju ove zagonetke ponudiće mu grammatica speculativa Dunsa Skota $^{3}$, jedna logika jezika ('Sprachlogik'), kako je naziva Karl Verner, čiji članak o Dunsu Skotu Hajdeger izlaže kritici u svom habilitacionom radu. Srednjovekovna ideja spekulativne gramatike poslužiće Hajdegeru da u teoriji značenja Dunsa Skota prepozna jednu vrstu preteče Huserlove fenomenologije, ujedno pružajući mu nadu da ona, sada u svojoj fenomenološkoj interpretaciji, može dati svoj doprinos modernoj logici.

„Spor“ između logike i jezika u liku gramatike samim tim neće biti zataškan, što će već potvrditi i frajburška posleratna predavanja u kojima će problem odnosa logike i jezika dobiti svoju artikulaciju u Hajdegerovom tumačenju antičkog pojma $\lambda$ ófos-a i njegovom okretanju Aristotelu. Za razliku od sholastičkih mislilaca i zastupnika tradicionalne logike Hajdeger kao polazište u svojoj destrukciji pojma $\lambda$ ó $\gamma$ os-a neće uzeti Aristotelov „Organon“ nego njegovu, prema sopstvenom mišljenju, neopravdano zapostavljenu „Retoriku“. Odnos logike i jezika u Hajdegerovoj filozofiji postepeno će se preokrenuti, interesovanje za temu jezika vremenom će jačati da bi u jednom trenutku prevagnulo. Prema Hajdegerovom priznanju, presudni trenutak poklopiće se sa njegovim predavanjem iz sredine tridesetih godina $u$ kome će pitanja

${ }^{3}$ Spis De modis significandi sive Grammatica speculativa, dugo pripisavan Dunsu Skotu, inače je delo Tome od Erfurta koji je pripadao školi Dunsa Skota. 
logike ustupiti mesto razmatranju suštine jezika. Nameće se onda pitanje da li Hajdegerov „okret ka jeziku“, koji će obeležiti kasni period njegove filozofije, predstavlja samo krajnji stupanj sazrevanja misli čiji se zametak može pronaći već u njegovim ranim spisima koji se bave problemom logike.

\section{HAJDEGEROVA RANA LOGIČKA ISTRAŽIVANJA}

Svoja predavanja o logici Hajdeger će držati gotovo tokom cele svoje predavačke karijere. Počev još od vremena kada je bio docent pa sve do sredine tridesetih godina, nakon silaska sa mesta rektora Frajburškog univerziteta, on će im se redovno vraćati. ${ }^{4}$ Već u svom predratnom spisu „Novija istraživanja o logici“ Hajdeger će svečanim tonom utvrditi da zbog težine koju problem logike sa sobom nosi, njegovo rešenje mora biti ostavljeno za budućnost (Heidegger 1978: 18). Ni prelomno predavanje „Logika kao pitanje o suštini jezika“ iz 1934. godine neće biti poslednje koje će u svom nazivu sadržati reč logika, s tim da će počev od tog predavanja, kao što i sam njegov naslov govori, predmet razmatranja biti jezik. Najvećeg udela u Hajdegerovoj istrajnoj posvećenosti problemima logike imaće svakako Huserlova „Logička istraživanja“. Uprkos svom nespornom revolucionarnom karakteru, Huserlovo prekretničko delo uslediće kao kulminacija sporova u kojima će se s kraja 19. veka lomiti koplja oko pojma logike, a čiju lavinu će pokrenuti delo napisano izvan nemačkog govornog područja. „Sistem logike“ Džona Stjuarta Mila iz 1843. godine nakon svog prvog prevoda na nemački jezik do pojave Huserlovih „Logičkih istraživanja“ doživeće višestruka reizdanja, da će se i sam Huserl u svojoj knjizi na njega pozivati, uprkos tome što će mu Milova „Logika“ poslužiti kao predmet kritike. U osvit „doba psihologije“ Milovo delo će svojom dozom

\footnotetext{
${ }^{4}$ Pored predavanja iz 1925. i 1928. godine, i pomenutog predavanja iz sredine tridesetih godina, ne treba zaboraviti ni poslednje frajburško predavanje uoči Hajdegerovog odlaska u Marburg, „Ontologija - Hermeneutika faktičnosti““ iz 1923. godine, koje je takođe trebalo da nosi naziv „Logika“. Prvobitni naslov predavanja je izmenjen iz tehničkih razloga, jer je, navodno, jedan drugi kurs iz logike već bio prijavljen.
} 
empirizma u drugoj polovini 19. veka provocirati pojavu nekoliko „Logika“ koje će podstaknute njime ujedno nastojati da ga nadmaše. Između ostalih, dovoljno je spomenuti samo Loceovu, Vuntovu, Erdmanovu i Zigvartovu „Logiku”. Ovaj amalgam psihologije, lingvistike i logike koji će u Huserlovim „Prolegomenama za čistu logiku“ naići na osudu, kao pojava biće prethodno trajno denotiran od strane Gotloba Fregea kao „psihologizam“, iako će njegova konotacija vremenom varirati. Pri tom, kao jedan od predmeta svoje kritike, Frege će izabrati upravo Huserlovo delo „Filozofija aritmetike“, što će na Huserla, uprkos ovoj kritici, imati presudan efekat.

Iste godine kada će objaviti „Bivstvovanje i vreme“, u predavanju „Temeljni problemi fenomenologije“, Hajdeger će i dalje Huserlu pripisivati u zaslugu da je prvi posle Kanta ponovo „uneo svetlo u logiku“, mada će ona, prema njegovom mišljenju, kao zasebna nauka kod Huserla ostati izvan filozofije (Heidegger 2006: 198). Logici će, nasuprot tome, u Kantovoj filozofiji, prema Hajdegeru, biti dodeljeno centralno mesto, što neće zaseniti ni činjenica da će Kant tokom cele svoje nastavne delatnosti marljivo predavati školsku logiku. Hegelov pokušaj revitalizovanja logike, s druge strane, neće za Hajdegera odmaći dalje od njenog tradicionalnog pojma. Hajdeger će rado navoditi Kantovu tvrdnju iz predgovora drugog izdanja „Kritike čistog uma“, kako logika od Aristotela naovamo nije napravila nijedan korak unazad, ali ni unapred, već da je kao takva zaokružena i završena. U zavisnosti od toga kako se Hajdegerov odnos prema logici bude menjao, ova Kantova rečenica će u njegovoj interpretaciji poprimati različita značenja. U svojim prvim posleratnim predavanjima o Aristotelu on će tako tvrditi da je Kantu, zbog nedostatka temeljnog iskustva koje omogućava radikalnu postavku problema logike, bio onemogućen pristup istinskoj logici, a ova zauzvrat kod njega bila zamenjena „pseudo-aristotelovskom logikom“ (Heidegger 1994: 21). To što će vremenom Hajdeger u znatno povoljnijem svetlu tumačiti Kantov doprinos logici neće ga ipak, u konačnom, sprečiti da u davanju primata logici, koja je prema neokantovcima trebalo da bude podređena epistemologiji i time, navodno, svedena na ulogu ,predsoblja nauke“, vidi razlog što će u tumačenju Kantove prve „Kritike“ ontološki plan biti zanemaren. Nasuprot novokantovcima, koje će „povratak 
Kantu“ navodno odvesti jednoj vrsti hegelovskog „panlogizma“, Hajdeger će se zalagati za to da umesto konačnog „rastvaranja ontologije u logiku“, obrnutim putem, logika ponovo bude ,primljena nazad u ontologiju“ (Heidegger 2006: 198). U kontekstu posthegelovske filozofije Kantova tvrdnja o završenosti logike, reaktualizovana od strane Hajdegera, značiće tako znatno više od pukog kurioziteta i lekcije iz istorije filozofije. Time što će uperiti oštricu svoje kritike prema Hegelovoj logici, Hajdegeru će preostati samo jedna mogućnost, naime, da logiku u njenom dovršenom obliku „iz njene osnove istavi iz ležišta“ (Hajdeger 1997: 170).

U osnovi gledano, Hajdegerov ambivalentni odnos prema Kantovoj logici samo odražava prirodu problema pred kojim se, upravo sledeći trag Kantove filozofije, našla logička misao 19. veka. Jedan prikaz razvoja logike nakon Kanta može se naći u članku Vilhelma Vindelbanda „Logika“ iz 1912. godine, koji i sam Hajdeger navodi. Vindelband će, takođe, podsetiti na Kantovu konstataciju da je opšta logika kao dovršena građevina sklona samo još neznatnim izmenama i ukazati na napetost koja postoji između ove tradicionalne logike, koja, prema Kantu, treba da putem svojih analitičkih formi lišenih svake stvarne saznajne moći u vidu običnog korektiva mišljenja obezbedi negativni kriterijum istine, i Kantovog pojma transcendentalne logike kao logike istine sa njenim sintetičkim formama koje imaju konstitutivnu funkciju za celokupni svet pojava (Windelband 1912: 183-184). Svaka reforma logike, prema Vindelbandu, otuda će podrazumevati pronalaženje istinske veze formalne i materijalne logike, a za polazište uzeće mesto njihovog „srastanja“, učenje o sudu. Oslanjajući se na Locea i Zigvarta kao predstavnike dominantnog razvojnog pravca logike koji će, dajući primat Kantovom pojmu transcendentalne logike, nastojati da izvrše reviziju stare logike, Vindelband će nedovoljnost Kantove formalne logike videti u njenom nekritičkom usvajanju formi suda iz Aristotelove logike i zato kao osnovni zadatak logike postaviti iznalaženje jednog novog učenja o sudu.

Značaj koje će učenje o sudu imati u okviru novih tendencija na području logičkih istraživanja neće proći bez odjeka u Hajdegerovim ranim radovima. Njegov doktorski rad „Učenje o sudu u psihologizmu“ 
iz 1913. godine, već će svojim izborom teme potvrditi odanost novokantovskoj struji, u ovom slučaju, njenom jugozapadnom krilu, takozvanoj Badenskoj školi, za čije će domete pored Vindelbanda kao njenog osnivača, najviše zasluga imati njegov naslednik Hajnrih Rikert. Iako će Rikert biti Hajdegerov mentor, neposredni uticaj na Hajdegerov izbor doktorske teme imaće delo Rikertovog učenika Emila Laska, „Učenje o sudu“, objavljeno godinu dana ranije. Posebnim doprinosom Laskovog učenja o sudu Hajdeger će smatrati njegov pokušaj revizije Kantove transcendentalne logike, njenim produbljivanjem i dopunjavanjem teorijom predikacije, kao i proširivanjem sfere primene kategorija na područje vrednosti (onog važećeg). U želji da nadomesti navodne nedostatke Kantove nepotpune adaptacije Aristotelovog učenja o kategorijama unutar svoje filozofije, pomirivši razlike između njih, i samim tim ovu dvojicu filozofa dovevši, koliko je to moguće, bliže jedan drugome, Lask će namesto Kantovog pojma suda kao supsumcije čulnog materijala pod kategorije razuma postaviti spoj kategorijalne forme (predikat) i alogičkog materijala (subjekat). Prednost Laskove teorije predikacije, između ostalog, ležaće u tome što se može primeniti i na impersonalne rečenice, koje zbog svoje primitivne forme predstavljaju neželjeni teret za svaku naučnu logiku. Logička forma suda i njegov gramatički oblik, u kojem ga obično zatičemo, mogu da prate jedno drugo, ali ne moraju da se jednoznačno podudaraju. Svestan da logika ne treba da bude vođena gramatikom, jer gramatičke razlike ne impliciraju nužno i logičke razlike, Lask će oštro razdvojiti ove dve oblasti i zagovarati oslobađanje logike od štetnog dejstva gramatike.

Hajdegerova doktorska disertacija „Učenje o sudu u psihologizmu“" otkriće u svom jezgru zajednički koren Laskovog učenja o sudu i Huserlove kritike psihologizma. Huserlova kritika izložena u „Prolegomenama za čistu logiku“ pomoći će Lasku da unutar same novokantovske normativne teorije pronađe recidive psihologizma. Ova zamerka upućena novokantovstvu da je u njenom krilu odgajan psihologizam biće karakteristična. Neretko će se dešavati da se oni koji su doskora drugima prebacivali psihologizam, ubrzo zatim sami nađu na strani okrivljenih. Oštro razdvajanje logike i psihologije ni za mladoga Hajdegera nije bilo lako izvodljivo, jer je „logičko ugrađeno u psihičko“ 
(Heidegger 1978: 29-30). Bez obzira na to, u svom doktorskom radu on će nastojati da ukaže na opasnost od utapanja logike u psihologiju koja preti u srcu logičke teorije, u učenju o sudu, putem detektovanja zaostalih tragova psihologizma u učenjima Vunta, Majera, Lipsa i Brentana. Probni kamen svake od ovih teorija suda, međutim, činiće njihova uspešnost u rešavanju problema koji se javljaju kod primera graničnih formi suda kao što su bezlične rečenice (impersonalije), pitanja, negativni, egzistencijalni i hipotetički sudovi. Upravo neke od ovih graničnih fenomena, od kojih će istaknuto mesto zauzeti problem pitanja, Hajdeger će već u svom članku „Novija istraživanja o logici“ naznačiti kao slučajeve kod kojih psihološka istraživanja jezika mogu biti dragocena, jer se ovim gramatičkim formama, navodno, ne može pristupiti „ni čisto logički, ni čisto psihološki“" (Heidegger 1978: 32).

Priroda ovih jezičkih formi i problemi koje one sa sobom nose izneće na videlo pitanje uplitanja psihologije i logike. Granica koju će Hajdeger povući, između činjenice da psihologija za logiku čini samo početno polje delovanja, njenu operacionalnu bazu, i neopravdanog pokušaja da se na njoj zasnivaju logička načela (Heidegger 1978: 29), često ce biti zamagljena. Glavni zadatak Hajdegerovog razmatranja savremenih psiholoških učenja o sudu predstavljaće upravo otkrivanje primera prelaženja te granice, što se najbolje može ilustrovati na primeru teorije suda Hajnriha Majera, sledbenika Kristofa von Zigvarta čija će logika, inače, biti jedan od glavnih predmeta Huserlove kritike. Majer će poći od pretpostavke da gramatička forma iskazne rečenice ne otelovljuje izvornu formu suda, već da tu ulogu pre zaslužuju impersonalni sudovi, kao pravi surogati primitivnih sudova. Mada će Majerovo navodno insistiranje da logika mora biti „usidrena“ u psihologiji, proisteklo iz potrebe da se ona razgraniči sa gramatikom, biti kritikovano od Hajdegera zbog navodnog poistovećivanja gramatičkih primitivnih sudova sa elementarnim sudovima logike (Heidegger 1978: 112-113), njegova teorija primitivnih sudova u kojoj gramatička forma iskaza ima izvedeni karakter, daće podsticaje za Laskovu metagramatičku teoriju predikacije. Lask će se voditi razlikovanjem psihološko-gramatičke strukture suda i njegovog stvarnog logičkog smisla. Videvši u pozadini tradicionalne gramatičke podele na subjekat i predikat samo jedan 
psihološki sled, on će nastojati da pokaže kako gramatička forma suda zakriva logičku formu. Prednosti koje pruža Laskovo jasno odeljivanje logike od gramatike, očito, neće biti dovoljne, jer će se Hajdeger u svom habilitacionom spisu okrenuti Huserlovoj ideji čiste gramatike. Međutim, kao što će to učiniti još u svom doktoratu, i u habilitacionom radu Hajdeger će pokušati da pronađe srednji put između Huserlove fenomenologije i Laskovog učenja o sudu.

\section{ODNOS GRAMATIKE I LOGIKE}

Drugi tom svojih „Logičkih istraživanja“ Edmund Huserl će započeti napomenom da izgradnja čiste logike mora neizostavno započeti analizom jezika kao jednom vrstom ,predradnje“. Jedan dublji motiv da se otpočne sa razmatranjem jezika, za Huserla, biće da se pripomogne u izradi pravih objekata logičkog istraživanja, koji su nam prvobitno dati „, gramatičkom ruhu“ (Husserl 2005: 7). Mora se ojačati povratna veza logičkih pojmova i zora, vratiti im se njihova konkretna punoća, umesto da se zadovoljimo samo njihovim pukim simboličkim značenjima koja počivaju na odumrlim vezama sa udaljenim zorovima. Oživljavanje ovih veza ostvaruje se putem dovođenja do zornosti ('Veranschaulichung') promenljivih značenja koja „prirastaju“ uz jedan logički termin. Nadovezujući se na Milovu konstataciju da je jezik najplemenitije čovekovo oruđe i sredstvo mišljenja koje je ujedno najosetljivije i najsklonije greškama, Huserl će kao meru predostrožnosti zbog nesavršenosti jezika kao pomoćnog sredstva strogog istraživanja, istaći neophodnost jasnog definisanja termina usled njihove opterećenosti ekvivokacijama. Ova nepoverljivost prema jeziku objediniće različite filozofske škole i pravce, od Bergsonovog poziva da slomimo okvire jezika koji „,razara ili bar skriva tanane i nestalne utiske naše individualne svesti“ (Bergson 1978: 62, 63), sve do Fregea, koji kao jedan od zadataka filozofije vidi slamanje vladavine reči nad ljudskim duhom (Frege 1993: XII). Od mere podozrenja koje će filozofska misao gajiti po pitanju jezika zavisiće i njen odnos prema gramatici. Za Huserla ovaj odnos neće biti listom negativan, jer pored činjenice da jezik „koči“ mišljenje, istina je da ga on istovremeno „podupire“ (Husserl 1970: 371). Sa problemom 
odnosa mišljenja i jezika filozofija će se suočiti već na samim svojim počecima što će se prvenstveno odraziti na pojavu njene terminologije. Racionalna misao će kasnije, otišavši predaleko u svojoj želji da jezik podredi sebi, započeti izgradnju opšte gramatike, jedne racionalne nauke o nepromenljivim i opštim principima jezika. Pokušaj konstrukcije formalnog jezika putem pročišćavanja i uprošćavanja prirodnog jezika dostići će svoj vrhunac u Lajbnicovoj characteristica universalis koja će uprkos svom utopijskom karakteru poslužiti kao uzor za Fregeovo pojmovno pismo. Nastojanje logike da izbegne zamke u koje je upadala sledivši tesno jezik i gramatiku, odvešće je tako logistici. Za razliku od Huserla, za koga će jedina opasnost logici pretiti od strane psihologizma, Hajdeger će već u svojim ranim spisima izraziti bojazan u vezi sa pojavom formalizma u logici, pogotovo kada je reč o nemoći logistike da putem matematičkih simbola i pojma funkcije valjano pristupi problemu značenja u okviru učenja o sudu (Heidegger 1978: 42-43).

Iako predmet Huserlovih razmatranja neće biti jezik kao takav, to samim tim neće značiti da njegov pristup problemu jezika neće prevazilaziti uske metodološke okvire filozofske terminologije. Štaviše, jezik će se naći u srcu fenomenološke problematike, i to u liku gramatike. Od analize gramatičkih struktura jezika zavisiće mogućnost čiste logike. Za Huserla će u tom cilju biti od važnosti da prethodno jasno razgraniči gramatičku analizu od analize značenja, sa kojom se ona obično neopravdano poistovećuje. U korenu ovog paralelizma, prema Huserlu, leži tendencija da se, zbog ,,sirovog“" podudaranja govora i misli, za svako razlikovanje u gramatici traži njegov pandan u logici. Nesvodivost logičkih razlika na gramatičke, da jedne i druge ,ne idu ruku podruku“, nije nikakva filozofska novost. Poznata je kasna Hegelova tvrdnja, na tragu Humboltovih istraživanja, da jezik kod najobrazovanijih naroda ima najnesavršeniju gramatiku, odnosno, da gramatička forma slabi u korist onog logičkog (Hegel 1987: 391). Prema Huserlu, međutim, ne sme se samo ostati pri opštoj činjenici o nekoincidenciji logičkog i gramatičkog razlikovanja. Time bi se samo suzilo polje logike bogato značajnim logičkim razlikama, a ove otpremile u red puko gramatičkih. Suprotno od Huserla, Hejman Štajntal će, na primer, negirajući mogućnost jedne filozofske gramatike, kao jedinu njenu moguću zaslugu videti u tome što 
bi se njome logika rešila jednog ometajućeg balasta. Za Štajntala, na kritici čijeg stanovišta će, između ostalog, Huserl bazirati sopstvenu poziciju, postoje samo dva rešenja problema odnosa logike i gramatike: ili da logika ,proguta“ gramatiku ili da gramatika bude potpuno slobodna od logike (Steinthal 1881: 68). Gledano kroz povest filozofije, prema Štajntalu, tokom dva milenijuma njihovog slučenog postojanja, gramatika se spram logike nalazila u podređenom položaju, pod njenom vlašću. Prvi gramatičari, počev od onih koji sebe ispočetka nisu ni nazivali tim imenom, kao i gramatičari Por Rojala, izvodili su gramatiku iz logike, kao logičku gramatiku. Međutim, iz neodvojivosti jezika i misli, samim tim ne sledi njihovo jedinstvo i istost, što prema Štajntalu potvrđuje i činjenica da se i najveće besmislenosti daju pravilno i u lepom rečeničnom sklopu izraziti. Huserl će ovaj prigovor iskoristiti da napravi distinkciju između besmisla ('Unsinn', nesmisao), od kojeg nas čuvaju apriorni zakoni značenja, i formalnog protivsmisla ('Widersinn'), od kojih nas štite logički zakoni u pregnantnom smislu. Ova distinkcija, zajedno sa sholastičkim razlikovanjem kategorematskih i sinkategorematskih izraza prenesenim na teoriju značenja, poslužiće mu kao protivargument Štajntalovom negiranju mogućnosti jedne, prema rečima ovog drugog, logičke (,idealne“) gramatike, koja bi, budući „ni logika ni gramatika“, već jedna vrsta međukarike, izražavala, gledano iz ugla prve, zahteve logike prema jeziku, a ako se pođe od druge, potrebu jezika za svojom logičkom stranom (Steinthal 1881: 63-64).

Otklonivši sve prigovore upućene na račun jedne, od Štajntala prozvane, filozofske logike, Huserl će upravo izabrati put od kog je Štajntalova kritika želela da odvrati. Uprkos Fregeovoj tvrdnji da psihologija kroz gramatiku širi svoj uticaj iskrivljujući naše mišljenje, Huserl neće želeti da gramatiku prepusti u ruke psihologiji. Njemu će stara ideja opšte gramatike postati bliska, a njoj će ga odvesti upravo kritika psihologizma i ideja čiste logike. Zamisao univerzalne gramatike, rođena unutar Por Rojala, o idealnom jezgru svih jezika, dobiće, prema Huserlu, svoje utemeljenje u njegovoj apriornoj gramatici. Ova idealna gramatika sa svojim zakonima koji određuju moguće forme značenja, odnosno, granice smisla, a nisu u punom smislu logički zakoni, zauzima jedan deo čiste logike koji bi se, sledstveno tome, mogao nazvati čisto 
logičko gramatičkim. Do ovih čistih gramatičkih struktura koje čine idealni skelet jezika, njegovu idealnu formu, dolazi se destilacijom iz prethodno date gramatičke strukture nekog postojećeg jezika. Huserl će tako slično Humboltu verovati da svaki jezik ima svoje apriorne temelje, s tim da on za razliku od Humbolta neće jeziku dodeliti ulogu oblikovaoca misli.

Još jedna tradicija, koja stoji u senci racionalističke ideje univerzalne gramatike, koja joj je prethodila i na koju se posredno naslanjaju Huserlova istraživanja na planu apriorne gramatike, jeste kasnosholastička misao jezika. Nastala iz potrebe da se prevaziđu uske granice jedne pedagoški orijentisane gramatike, sholastička spekulativna gramatika je, pored pružanja principa kojima je svaki jezik morao da podleže, ujedno trebalo da odražava univerzalne istine o svetu. Pretpostavka o izomorfnosti struktura sveta i struktura jezika počiva na ideji božanskog reda koji uspostavlja odnose zavisnosti između jezika, misli i spoljašnjeg sveta. Zakoni gramatike tako dobijaju svoju legitimaciju izvan sfere jezika, pošto se u njemu ogledaju struktura misli, odnosno, struktura sveta. Najznačajnije delo kasnosholastičke misli iz oblasti jezika De modis significandi („O načinima označavanja“) nosi zato paralelni naslov Grammatica speculativa (speculum - ogledalo). Ovo delo, dugo vremena greškom pripisivano Jovanu Dunsu Skotu, naći će pomena i u Štajntalovoj knjizi „Uvod u psihologiju i nauku o jeziku“, u poglavlju posvećenom odnosu gramatike i logike, na koje upućuje i Huserl u svojim „Logičkim istraživanjima“. Vođen Huserlovim uputima, mladi Hajdeger, koji i sam navodi Štajntalovu knjigu, pokušaće zatim da svojim habilitacionim radom „Učenje Dunsa Skota o kategorijama i značenju“ ponudi nedostajuću kariku koja bi povezivala srednjovekovnu ideju spekulativne gramatike i Huserlovo učenje o značenju.

\section{GRAMMATICA SPECULATIVA}

Prema rečima Džona Kaputa, veoma bi se lako moglo podleći iskušenju i Hajdegerov habilitacioni rad otpisati kao proizvod njegove mladosti koji je on u potpunosti ostavio iza sebe, što se, sudeći prema tome koliko je ovo delo zapostavljeno u filozofskoj literaturi, upravo i 
dogodilo (Caputo 1974: 101). Iako je gotovo pola veka prošlo otkako je Kaputo u svom članku „Phenomenology, Mysticism, and the Grammatica speculativa“, pokušao jednu vrstu revalorizacije Hajdegerovog ranog spisa, stanje se nije mnogo izmenilo. Hajdegerov habilitacioni rad i dalje tavori u senci njegovih kasnijih dela koja će mu doneti zasluženu slavu. Stojeći na razmeđi njegovih ranih prodora $u$ područje filozofije i zrele faze mišljenja, ovo delo, u osnovi, predstavlja pravi početak Hajdegerove filozofije. Samim tim ono sadrži sve elemente njegovog filozofskog postupka i naznake onoga što će tek doći. Mada neće još poprimiti oblik metode destrukcije, Hajdegerova analiza jednog problema sholastičke filozofije neće predstavljati običan izlet $\mathrm{u}$ istoriju filozofije. Na primeru pokušaja prevrednovanja sholastičke tradicije, putem revizije usađenih shvatanja koja se tiču njenog formalizma, Hajdeger će demonstrirati svoj postupak pronalaženja novih prilaza filozofskim učenjima koje im ne pristupa sa lažnim osećanjem koje se gaji prema antikvarnim predmetima. Već u naslovu naknadno pripojenog uvoda rada, biće skrenuta pažnja na nužnost problemski orijentisanog pristupa povesti filozofije, što će biti podcrtano i jednim Hegelovim citatom da $\mathrm{u}$ stvarima filozofije ne vlada podela na prethodnike $\mathrm{i}$ sledbenike (Heidegger 1978: 193). Umesto predstave napretka, rezervisane za područje nauke, na planu povesti filozofije, prema Hajdegeru, može se govoriti jedino o stalnom traženju novih pristupa unutar jednog istog kruga filozofskih problema. Ovaj pristup povesti filozofije kao povesti problema, koji će iznedriti i promovisati novokantovska škola, Hajdeger će, međutim, ubrzo napustiti i izložiti kritici. Teškoće na koje će naići novokantovci u nastojanju da pomire razlike između sistematskog i povesnog pristupa istraživanju, ukazaće mu na neophodnost traženja izvornijeg prilaza povesno-filozofskim pitanjima.

Nedostatak osvešćenosti metodskog pristupa i nedovoljna doza odvažnosti i slobode potrebne da bi se krčio put u nova područja znanja, koji, za razliku od moderne misli, karakteriše kasnu sholastiku, neće, međutim, umanjiti Hajdegerovo uverenje da ova druga, uprkos ustaljenim verovanjima, u mnogim svojim aspektima pokazuje moderne crte. Ona će za Hajdegera predstavljati bogatu tradiciju sistemski uređenih temeljnih 
pojmova, koja pod svetlom novonastalih tendencija na polju logike ne samo da iznova oživljava, nego i pruža nove podsticaje. Osobenosti srednjovekovnog iskustva sveta lišenog negativnih uticaja savremene psihologije Hajdeger će iskoristiti kao argument protiv psihologizma, a u korist Huserlove fenomenologije, sa kojom će kasnosholastička misao, navodno, pokazati veliku srodnost. U sholastičkom pristupu, koji u analizi značenja ostaje kod deskriptivnog sadržaja, bez zapadanja u empirijsko genetička objašnjenja, on će videti sličnost sa Huserlovom metodom, kao što će u sholastičkoj psihologiji koja zadržava usmerenje ka predmetu, za razliku od moderne psihologije koja polazi od čoveka utonulog u svet čulnih utisaka, pronaći paralelu sa Huserlovim isticanjem intencionalnosti svesti. ${ }^{5}$

Hajdegerov habilitacioni spis ne bi valjalo, stoga, tumačiti kao okret ka sholastici, a pogotovo bi pogrešno bilo njegov afirmativni stav o sholastičkoj misli shvatiti kao posledicu oportunizma jer je izbor teme rada diktirao konkurs za mesto profesora na katedri Katoličkog teološkog fakulteta. U prilog poslednjoj tezi lako bi se mogle navesti Hajdegerove potonje tvrdnje uperene protiv sholastičke logike, kako je, na primer, ova tradicionalna školska logika zadržala sadržaj izvornog filozofskog pîtanja koje još bilo živo kod Platona i Aristotela, ali u otuđenoj i otvrdloj formi (Heidegger 1976: 13). Kasnije Hajdegerove izjave koje su se doticale sholastike retko će dosezati nivo stava, iznetog u habilitacionom spisu, o netačnosti tvrdnje da sholastička logika ne dopire dalje od silogističkog „sitničarenja“ i puke prepravke Aristotelove logike (Heidegger 1978: 202). Osvrt na sholastičku tradiciju Hajdegeru će poslužiti kao poligon za polemiku sa savremenim učenjima o logici, ali to ne baca senku na njegov povesno-filozofski zahvat. Hajdegerovo naknadno priznanje da bez teološkog obrazovanja ne bi nikada dospeo na put filozofije moglo bi biti od koristi u analizi njegovog habilitacionog rada, ali njegov značaj, takođe, ne treba prenaglašavati. Nije tajna da je u svom ranom periodu filozofskog formiranja Hajdeger $u$ jednom trenutku bio privučen

\footnotetext{
${ }^{5} \mathrm{Ne}$ radi se o slučajnoj podudarnosti ako se ima na umu činjenica da je pojam intencionalnosti preuzet iz sholastičke tradicije i upravo zaslugom Huserlovog mentora Franca Brentana ponovo oživljen.
} 
antimodernističkim strujama koje će za posledicu imati rađanje neosholastičke filozofije $\mathrm{s}$ početka prošlog veka $\mathrm{i}$ da će taj antimodernizam kasnije uticati na njegovu misao. Iako su srednjovekovna filozofija i teologija u zrenju večnih istina nudile zaklon od relativizma i subjektivizma modernih pravaca $u$ filozofiji, već na samom početku Hajdeger će biti otvoren za dijalog sa modernom filozofskom misli čijoj privlačnoj sili ipak neće odoleti i naspram čije širine će mu uskost pogleda neosholastičkih shvatanja postati neprihvatljiva. I sama činjenica da će se pre opredeliti za mislioce kasne sholastike, poput Okama i Dunsa Skota, a ne za Tomu Akvinskog, govori u prilog tome.

Nešto čime moderna filozofija ne može da se pohvali, a bitna je odlika sholastičke filozofije, jeste da je ova neodvojiva od srednjovekovnog pogleda na svet u čijem središtu stoji tomistička postavka analogije bića (analogia entis), ideja da sva bića svoje postojanje duguju u meri u kojoj učestvuju u božanskom logosu. Budući mnogo više od školskog pojma, analogija je, prema Hajdegeru, pojmovni izraz „doživljajnog sveta srednjovekovnog čoveka, [...] određene forme unutarnjeg tubivstvovanja usidrenog $\mathrm{u}$ transcendentni praodnos duše ka bogu“ (Heidegger 1978: 409). U ovom odnosu čovek ne žrtvuje svoju individualnost, već je ona spojiva sa transcendentnošću boga, kao što su sholastika i mistika, za Hajdegera, samo dve strane srednjovekovnog pogleda na svet, od kojih ako jedna pretegne, nužno zapada u krajnost. Kao što misticizam može da zapadne u besciljni iracionalizam, filozofija, ukoliko je odeljena od života, kao racionalna tvorevina postaje besplodna i nemoćna (Heidegger 1978: 410). Upravo ova blizina realnom životu, kako će, inače, Hajdeger čitati Skotov pojam haecceitas, jeste ono što će njega, prema sopstvenom priznanju, privući Dunsu Skotu i u čemu će on prepoznati modernost njegove misli. Uslov da filozofija mora ostati bliska životu Hajdeger će primeniti i na rešenje odnosa gramatike i logike. On će uslovno zastupati odvajanje jezičkih struktura od njihovog logičkog sadržaja. Jasno je da sama reč ne poseduje intencionalan karakter, da u rečima kao takvim nema povezanosti i reda, i da su one ništa drugo do konglomerati lišeni značenja i smisla. Međutim, izuzme li se korist koja bi se mogla imati od uvida u njihovu heterogenu prirodu, oštro deljenje gramatičkih i logičkih struktura trebalo bi, prema 
Hajdegeru, ukinuti jer pada u zaborav onog trenutka kada se ,živi u saznanju“ (Heidegger 1978: 295). ${ }^{6}$ Za onoga ko živi u aktualnom govoru, sfera gramatike i sfera logike stapaju se u jednu, a strukture jezika, samim tim, gube svoj alogički karakter. Sledeći srednjovekovne gramatičare (modiste) koji su uspostavljali odnos slaganja između načina na koji stvari jesu (modi essendi), načina na koji mislimo o njima (modi intelligendi) $\mathrm{i}$, konačno, načina na koji ove izražavamo u jeziku (modi significandi), Hajdeger će reći da „stvari stoje u mislima, a misli prianjaju ('haften') uz reči i rečenice“ (Heidegger 1978: 295). Smisao i značenje time posredstvom jezičkih struktura bivaju izrazivi. Ipak, ostaje nerešeno pitanje kakva je priroda veze jezičke forme i logičkog sadržaja i do koje mere ove jezičke strukture bremenite smislom mogu biti uključene u logiku.

Pojava spekulativne gramatike označava prelomni trenutak kada gramatika, dotada smatrana samo veštinom, u kasnoj sholastici biva uzdignuta na nivo nezavisne teorijske nauke i stavljena $u$ isti red sa matematikom, fizikom i metafizikom. Za razliku od Huserlovog isticanja potrebe odbrane filozofije od svake vrste psihologizma, koje će za rezultat imati ideju čiste gramatike, jačanje veze logike i gramatike u srednjovekovnoj filozofiji Dunsa Skota imalo je za razlog rešenje problema adekvatnosti ljudskog jezika kao sredstva predstavljanja boga i njegovih predikata. Gramatiku i logiku su usled njihovog uzajamnog preplitanja $u$ doba sholastike često delile samo nijanse (Jungen $\mathrm{i}$ Lohnstein 2007: 91). Iako će ova njihova bliskost ići naruku Hajdegerovom pokušaju da $\mathrm{u}$ sholastičkoj misli pronađe argumente za Huserlovo učenje o značenju, on će, takođe, morati da opovrgne primedbu da postuliranje jedne logike jezika mora ujedno da znači da gramatička upotreba jezika treba da bude izvedena iz logičkih zakona.

${ }^{6}$ Lask će jedno poglavlje svoje knjige „Logika filozofije i učenje o kategorijama“ nasloviti „Život i saznavanje“. Dok će nasuprot neposrednom doživljavanju onog „logički nagog“, „saznavanje“ tumačiti kao doživljavanje ('Erleben') logičke forme, on će, očigledno imajući na umu Huserlov pojam kategorijalnog zora, pod ,životom“ razumevati svako nereflektovano doživljavanje, uključujući doživljavanje onog nečulnog, „kao nečega predteorijskog“. Up. E. Lask, „Gesammelte Schriften“, Bd. 2, str. 191. 
Shodno tome Hajdeger će istaći kako modi significandi Dunsa Skota ne reprodukuju, odnosno, ne preslikavaju kategorije realne stvarnosti, već samo da odande „vode poreklo“ (Heidegger 1978: 339, 314-315). Zato je prvi deo Hajdegerovog habilitacionog rada, posvećen učenju o kategorijama, trebalo da u vidu jedne podstrukture pruži uporište za drugi, učenje o značenju.

U rešavanju problema nastalih Kantovim podastiranjem Aristotelovih kategorija tabeli sudova, putem proširenja teorije o kategorijama izvan granica tradicionalne logike, Hajdeger će naročito ceniti doprinose Vindelbanda i Laska, kao i Locea, čije će delo pripremiti pojavu novokantovstva. Od posebnog značaja biće Vindelbandovo uvođenje refleksivnih kategorija, kao i Laskov pokušaj zasnivanja jedinstveno shvaćene logike čija bi se primena proširila na područje svega znanoga. Kantovim preuzimanjem Aristotelovih kategorija i njihovim smeštanjem u okvir transcendentalne logike, prema Lasku, u drugi plan biće potisnuto sve ono formalno i refleksivno i samim tim neće biti obuhvaćena celina kategorija, već će one biti ograničene samo na jedan određeni domen, sferu čulnog iskustva. Čuvajući se, na drugoj strani, da ne upadne u zamku hegelovskog panlogizma, poštujući izvornu heterogenost sfera predmetnosti, Laskovo rešenje za vraćanje ugleda logike sastojaće se u jednoj „panarhiji logosa“. Na tragu Vindelbandovog i Rikertovog razdvajanja sfera istorijskih i prirodnih nauka koje je za cilj imalo zaštitu svojstvenosti istorijskih fenomena od njihovog zastiranja i izobličavanja od strane prirodnih nauka, Lask će, u želji da izbegne apsorpciju ateorijskog materijala od strane onog logičkog, zastupati njihovo strogo razdvajanje i umesto prožimanja, logičkoj formi dodeliti samo ulogu „legitimisanja“ sadržaja (njegovog „žigosanja“ ili „posvećenja“) (Lask 1923: 70). Nemogućnost da forma prožme sadržaj zbog njegove iracionalnosti, već samo da ga „zaogrne“, biće kod Laska kompenzovana redefinisanjem odnosa logičke forme i njenog sadržaja. Princip materijalne određenosti forme, činjenicu da forma ne vršeći nikakvu vrstu promene na materijalu predstavlja samo „način stajanja“ ('Bewandtnis') ili momenat jasnosti ('Klarheitsmoment') predmeta, prihvatiće i Hajdeger i pozvati se na njega $u$ drugom delu svog 
habilitacionog rada posvećenog učenju o značenju, kao i u njegovom zaključku.

Kao glavni zadatak prvog dela posvećenog učenju o kategorijama Hajdeger će zato postaviti „razgraničenje različitih područja predmetnosti na oblasti koje su kategorijalno nesvodive jedna na drugu“" (Heidegger 1978: 400). Svaki od ovih domena imao bi svoju logiku i svoju vodeću regionalnu kategoriju, što bi dovelo do potrebe za jednom „logikom logike" u kojoj bi neizostavno mesto našle refleksivne kategorije. Uprkos ulozi surogata konstitutivnih kategorija, refleksivne kategorije će posebnu pažnju zaslužiti u okviru Hajdegerovog razmatranja fenomena univokacije, analogije i ekvivokacije unutar drugog dela habilitacionog rada posvećenog učenju o značenju. Ova srednjovekovna problematika, nastala kao rezultat sholastičke egzegeze Aristotelovih logičkih spisa i želje da se antička filozofija pomiri sa zahtevima vere, Hajdegeru će biti poznata još iz Brentanovog ranog spisa „O raznim značenjima bivstvujućeg prema Aristotelu“.7 Njeno povezivanje sa savremenim filozofskim teorijama od strane Hajdegera imaće na umu prvenstveno njen mogući doprinos na polju novih učenja. Preovlađujuća uloga koju kategorije identiteta i diferencije igraju kod fenomena univokacije, ekvivokacije i analogije, Hajdegeru će samo ukazati na paralelnu prirodu refleksivnih kategorija i ovih načina funkcionisanja izraza. Osobina refleksivnih kategorija da su „stvorene kroz subjektivitet“, tako će, prema Hajdegeru, na strani pomenutih fenomena univokacije, ekvivokacije i analogije, odgovarati njihovom ,poreklu iz upotrebe izraza u živom mišljenju i saznavanju“ (Heidegger 1978: 335). S druge strane, nearbitrarnost primene i važenja refleksivnih kategorija, koja će kod Laska biti osigurana time što će i one, kao konstitutivne kategorije, na

\footnotetext{
${ }^{7} \mathrm{Na}$ tragu Aristotelove tvrdnje da se bivstvujuće kazuje mnogostruko, Brentano će pokušati da dokaže utemeljenost Aristotelove podele kategorija po uzoru na Adolfa Trendelenburga koji će kao potvrdu zasnovanosti kategorija uzeti njihovo gramatičko poreklo. Mada neće negirati ulogu gramatike kao niti vodilje u Aristotelovom određenju kategorija, Brentanu će se Trendelenburgovo pozivanje na slaganje kategorija sa jezičkim formama kao garanta valjanosti njihove podele činiti nedovoljnim. Up. F. Brentano, „Von der mannigfachen Bedeutung des Seiendes nach Aristoteles“, str. 194.
} 
kojima će parazitirati, biti određene materijalom, s tim da će se u njihovom slučaju raditi o sadržaju ,izbledelom“ do nivoa bivanja prostim sadržajem, na strani pomenutih načina funkcionisanja izraza imaće pandan u njihovoj ukotvljenosti u objektivnoj konstelaciji jezičkih izraza, njihovih značenja i pravaca ispunjenja (Heidegger 1978: 335-336). Unutar ove celine, u kojoj pomenuti fenomeni univokacije, ekvivokacije i analogije čine moguće veze inicirane od strane subjektiviteta, „očituje se u živom govoru i iskazu osobena pokretljivost ${ }^{8}$ značenja i njegovog ispunjenja nasuprot singularnom realitetu réči“ (Heidegger 1978: 336).

\section{OKRET KA METAFIZICI}

Period između odbrane habilitacionog rada i njegovog objavljivanja obeležiće iznenadna promena kursa Hajdegerove filozofije. Njeno oslobađanje od formalnih stega pratiće zaokret u mišljenju koji će biti glavni razlog postojeće napetosti između naknadno pripojenog zaključka rada i njegovog glavnog dêla. Stavljeni pod lupu metafizike, logički problemi su se sada morali razmatrati na širem planu povesne stvarnosti. Ukoliko, prema Hajdegeru, ostanemo zarobljeni unutar suženih šematskih okvira tabela kategorija, bićemo uskraćeni za „obilje oblikovnih pravaca živoga duha“, osuđeni na teorijsko „sricanje“ stvarnosti putem „provizornog sažimanja nabacane celine svega znanoga“ (Heidegger 1978: 406). Pored još izraženije potrebe da se na jednom mestu pomire zahtevi neosholastike, neokantovstva i fenomenologije, novina zaključka rada sastojaće se u tome što će ovom spisku sada biti pridodata i filozofija života. Njeno sve dominantnije prisustvo, pored fenomenologije, na drugoj strani pratiće postepeno opadanje uticaja novokantovstva, što će se pogotovo odnositi na njegovo jugozapadno krilo koje će izgubiti svoja dva

${ }^{8}$ Vindelband će govoriti o „slobodnoj pokretljivosti“" ('freie Beweglichkeit') koja vlada između svesti koja uspostavlja odnose i predstava koje obrazuju njen sadržaj. Up. W. Windelband, „Vom System der Kategorien“, str. 47. Na sličan način će i Bergson u „Stvaralačkoj evoluciji“, koja će se u nemačkom prevodu pojaviti 1912. godine, kao glavnu karakteristiku znakova ljudskog jezika umesto njihove opštosti istaći njihovu pokretljivost. Up. H. Bergson, „Schöpferische Entwicklung“, str. 163. 
predstavnika, Vilhelma Vindelbanda i Emila Laska. Odlazak Rikerta u Hajdelberg radi preuzimanja Vindelbandove katedre i dolazak Huserla u Frajburg kao njegovog naslednika predstavljaće simboličan čin silaska novokantovstva sa filozofske scene. U vreme objavljivanja habilitacionog rada Hajdegera će, međutim, sa novokantovstvom još uvek vezivati dovoljno čvrste veze. Poseban odnos Hajdeger će gajiti prema Laskovoj filozofiji čiji će jedan deo terminologije usvojiti. S obzirom na navodnu srodnost Laskove filozofske pozicije i kasnosholastičke misli Dunsa Skota, pojedini izrazi naći će mesta i u Hajdegerovoj interpretaciji srednjovekovnog pogleda na svet. Hajdeger tako govori o apsolutnoj predanosti ('Hingabe') srednjovekovnog čoveka, o njegovoj ,sklonosti da se preda u ruke materiji takvoj kakva jeste“ (Heidegger 1978: 198). Ovaj pojam Lask će uvesti još u svom predavanju „Postoji li 'primat praktičkog uma’ u logici?“. Na tragu Huserlove kritike psihologizma Lask će u želji da očuva objektivni status logičkih zakona izložiti kritici Rikertov normativno obojeni pojam „trebanja“ ('Sollen') koji će kao subjektivni korelat objektivnog važenja sadržati primese psihologizma i protivstaviti mu etički neutralan pojam predanosti kao „minimuma subjektivnog smisla“ (Lask 1991: 114). Dok će u njegovoj „Logici filozofije“ ovaj idealno postulirani oblik pasivne predanosti kao oblika filozofskog saznanja nečulnog materijala stajati nasuprot pojmu doživljavanja, u „Učenju o sudu“ će pod predanošću biti shvaćen jedinstveni pojam izvornog saznanja koji prethodi svakom obliku saznanja zasnovanom na sudu. Laskov „logički misticizam“ biće jedan od glavnih krivaca za Hajdegerovo obnovljeno zanimanje za mističku tradiciju koje će po prvi put postati evidentno u zaključku habilitacionog rada.

U zaključku rada, međutim, Hajdeger će napraviti jasan otklon od Laskove ideje panarhije logosa. Dok će za njega u glavnom delu rada nedostatak filozofije Dunsa Skota, pored njene sputanosti tradicijom, ležati u ostajanju na metalogičkom stanovištu (Heidegger 1978: 384), sada će on zahtevati da se logički problemi moraju sagledati u njihovom „translogičkom“ kontekstu (Heidegger 1978: 405). Kako će sada Hajdeger tvrditi, Laskova objektivna logika ostaće osuđena na jednostrano proučavanje strukture smisla, budući da će joj nedostajati jedan metafizički plan. Smeštanjem problema kategorija unutar razmatranja problematike 
suda i subjekta, što će Hajdeger označiti jednim od osnovnih zadataka učenja o kategorijama, ujedno će biti negiran sekundarni značaj Laskovog pojma suda kao razlaganja izvornog jedinstva predmetnog prauzora. Prema jednom Hajdegerovom pismu upućenom Rikertu, upravo će Rikertovo davanje prednosti „subjektivnom putu“ biti zaslužno za njegovo sopstveno udaljavanje od Laska (Heidegger i Rickert 2002: 48). ${ }^{9}$ Treće potpuno prerađeno i prošireno izdanje Rikertovog „Predmeta saznanja“, objavljeno u periodu između Hajdegerove odbrane habilitacionog rada i njegovog objavljivanja, sadržaće odgovor na Laskovu kritiku iznesenu u „Učenju o sudu“. Nasuprot Laskovom viđenju da svaki odnos prema subjektu remeti i podriva region predmeta, Rikert će zastupati stav da bi se uklanjanje pojma subjekta iz oblasti logičkoga moglo samo privremeno i „veštački“, a nikada konačno i stvarno sprovesti, jer bi u suprotnom vodilo u „dogmatički“" ontologizam i saznanje predmeta učinilo gotovo nerazumljivim (Rickert 1915: 288, 289). Pretpostavi li se da subjekt koji sudi dostavlja samo krivotvoreno saznanje, prema Rikertu, izrasta neizbežno pitanje o teorijskoj opravdanosti i zasnovanosti jednog saznanja koje nema formu suda.

Uprkos mogućem značaju koji će imati za Hajdegera, Rikertova kritika Laska ne nudi objašnjenje za Hajdegerov nagli okret ka metafizici u zaključku rada. Štaviše, radikalni prilaz strukturalnim problemima logike dovešće Laska, prema rečima Hajdegera, na sam prag metafizičke problematike (Heidegger 1978: 406). Povod za Hajdegerovo probuđeno zanimanje za metafiziku, koje će potvrditi i uvodni deo probnog predavanja „Pojam vremena $\mathrm{u}$ povesnoj nauci“, $\mathrm{u}$ kome će on govoriti o „metafizičkom porivu“ i „tendenciji ka metafizici“ (Heidegger 1978: 415), neće ležati samo u njegovoj privrženosti neosholastičkim korenima. Znatno pre njega, isti poziv za okretanje metafizici uputiće Vindelband u svom uvodu za nemačko izdanje Bergsonove „Materije i pamćenja“ iz 1908. godine (Bergson 1908: III). Vindelbandovo pozno vraćanje metafizici imaće za cilj jedno filozofsko učenje o pogledu na svet, u kom ključu bi se mogao tumačiti i Hajdegerov stav iz zaključnog poglavlja, da filozofija ne

\footnotetext{
${ }^{9} \mathrm{Ne}$ bi trebalo isključiti ni moguću ulogu Huserlovog transcendentalnog okreta u „Idejama“ u približavanju Hajdegera Rikertovoj poziciji i ujedno udaljavanje od Laska.
} 
može dugo opstati bez pomoći metafizike kao njene „istinske optike“ (Heidegger 1978: 406). Zahtev da se filozofija učini istinskim pogledom na svet u Hajdegerovom slučaju podrazumevaće ništa više do insistiranje da fragmentarni karakter svake teorije udaljene od života ustupi mesto bogatstvu ,živog duha“. U svojoj prepisci sa Rikertom Hajdeger će sada izjaviti da čista logika u liku jednog ekstrema predstavlja ,prikriveno nasilje nad živim duhom“, jer „filozofiji uskraćuje vezu sa temeljnim strujanjima ličnog života i bogatstvom kulture i duha“" (Heidegger i Rickert 2002: 38). Odbrana od svake vrste psihologizma zapašće, prema Hajdegeru, u drugu krajnost, u jednu oblast gde sva logika biva ugušena (Heidegger i Rickert 2002: 34). Posebno će biti značajna Hajdegerova tvrdnja da se oslanjanjem jedino na čistu logiku, bez pomoći metafizike, ne može rešiti problem negacije (Heidegger i Rickert 2002: 25). Da će Hajdegerovo interesovanje za gramatičke granične fenomene suda biti i dalje živo, potvrdiće i njegovo predavanje „Pitanje i sud“ dato u okviru Rikertovog seminara posvećenog Loceovoj „Logici“.

\section{ZAKLJUČAK}

Ono što je bilo samo nagovešteno u Hajdegerovom habilitacionom spisu, a tiče se njegovog razmatranja odnosa logike i jezika, već u prvim frajburškim predavanjima postaće očito - Hajdegerov stav preokrenuće se znatno na štetu logike. Odustavši od postavke jedne „,̌iste logike“, čije je utemeljenje zagovarao $\mathrm{u}$ svom predratnom doktoratu „Učenje o sudu $\mathrm{u}$ psihologizmu“ (Heidegger 1978: 186), on će već u predavanju „Ideja filozofije i problem pogleda na svet" iz 1919. godine filozofiji Paula Natorpa prebaciti navodnu apsolutizaciju i univerzalizaciju logičkog koja nije viđena još od Hegelovih dana (Heidegger 1999: 108). Analiza pojma $\lambda$ ófos-a, preduzeta od strane Hajdegera u okviru njegovih predavanja posvećenih Aristotelovoj filozofiji početkom dvadesetih godina, predstavljaće, u stvari, njegov pokušaj destrukcije logike. Hajdeger će $\lambda$ ófos prevesti kao govor ('Rede'). Uprkos njegovoj prethodnoj napomeni kako Grci nisu imali reč za jezik, time što će $\lambda$ ófos-u pripisati značenje 
žive reči i dovesti ga u blizinu jezika, ${ }^{10}$ Hajdeger će pokušati da ukine granicu između logike i jezika, i da istovremeno tradicionalnoj logici izmakne tlo pod nogama.

I u kasnijim predavanjima gramatika će biti predmet Hajdegerovih razmatranja, samo što će sada njena uloga biti razmatrana isključivo iz ugla pojma jezika. Pod svetlom novih uvida Hajdeger će zastupati stav kako se na niti vodilji $\lambda$ ófos-a shvaćenog kao iskaza govor još kod Grkâ sveo na teorijsko razmatranje, što je preko učenja o kategorijama u konačnom vodilo zasnivanju tradicionalne logike, kao i tome da gramatika bude pretvorena u nauku o jeziku. U predavanju „Pojam vremena“ iz 1924. godine Hajdeger će zato pledirati za vraćanje tradicionalne gramatike njenim osnovama (Heidegger 2004: 74-75). Budući da su gramatičke kategorije skrojene prema meri logike, mora se, po Hajdegeru, zaći iza njih ne bi li se omogućio pristup fenomenima i bivstvujuće zahvatilo u svom bivstvovanju. Dok će u svom habilitacionom radu naglašavati kako Skotovo jačanje veze logike i gramatike nije imalo za cilj da ovu drugu ugradi u logiku, već samo da razume logičke strukture značenja, on će u „Bivstvovanju i vremenu“ zagovarati „oslobađanje“ gramatike od logike (Heidegger 1985: 188).

Hajdegerov pokušaj da istrgne gramatiku iz zagrljaja logike biće kratkog daha, najviše iz razloga što će počivati na pretpostavci jedne hermeneutičke logike. Kao transcendentalno postavljanje pitanja, hermeneutika će, međutim, stupanjem Hajdegerovog mišljenja u područje povesti bivstvovanja, izgubiti svoje utemeljenje. Već u predavanju „Temeljni problemi fenomenologije“ iz letnjeg semestra 1927. godine, iste godine kada će Hajdeger objaviti svoje glavno delo, o njoj više neće biti pomena. Uvirući u razmatranje o suštini jezika, hermeneutika će polako napuštati scenu i prepuštati je temi jezika. Zajedno sa hermeneutikom biće odbačeni i planovi za izgradnju jedne izvorne logike, što će sâm govor o utemeljenju gramatike učiniti izlišnim. Samo dve godine nakon „Bivstvovanja i vremena“, neophodnost oslobađanja gramatike od prevlasti

\footnotetext{
${ }^{10}$ Još u predavanju posvećenom Platonovom „Sofistu“ iz 1924. godine Hajdeger

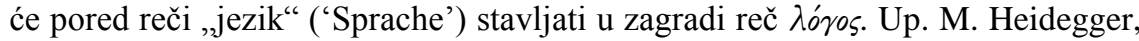
„Platon: Sophistes“, str. 17.
} 
logike ustupiće mesto potrebi oslobađanja jezika iz okova logike i gramatike (Heidegger 1983: 498). Prema Hajdegerovom tumačenju, logičko-gramatička predstava jezika odrediće bitno sudbinu jezika utrevši put otuđenju njegove suštine. Nasuprot ovoj dominantnoj struji ograničenog domašaja, uzor svakom razmatranju suštine jezika postaće pesništvo, kao izvorni i autentični vid javljanja jezika pred kojim svaka gramatička analiza neminovno zatajava.

U predavanju „Uvod u metafiziku“ iz 1935. godine sâm pojam logike Hajdegeru će se učiniti problematičnim. Iz tog razloga ju je ubuduće trebalo pisati pod znacima navoda. Slična sudbina zadesiće i gramatiku prema kojoj će Hajdeger biti pogotovo oštar:

Upravo tamo gde oživljava neki izvorni odnos prema jeziku, oseća se ono što je kod tih gramatičkih formi kao pukih mehanizama mrtvo. Jezik i razmatranje jezika sputali su se u tim krutim formama kao u nekoj mreži od čelika. Ti formalni pojmovi i gramatički nazivi postaju za nas, u pustom i duha lišenom izučavanju jezika u školi, prazne, sasvim nerazumljene i nerazumljive ljuske (Hajdeger 1997: 53-54).

\section{LITERATURA}

Bergson, Henri (1912), Schöpferische Entwicklung, prevela G. Kantorowicz, Jena: Eugen Diderichs.

Bergson, Henri (1978), Ogled o neposrednim činjenicama svesti, preveo F. Pašić, Beograd: Mladost.

Brentano, Franz (1862), Von der mannigfachen Bedeutung des Seiendes nach Aristoteles, Freiburg im Breisgau: Herder'sche Verlagshandlung.

Caputo, John D. (1974), „Phenomenology, Mysticism and the „Gramatica [sic] Speculativa“, A Study of Heidegger's „Habilitationsschrift", “ Journal of the British Society for Phenomenology, Vol. 5, No. 2: 101-117.

Frege, Gottlob (1993), Begriffsschrift und andere Aufsätze. Mit E. Husserls und H. Scholz Anmerkungen, 2. Aufl., I. Angelelli, Hildesheim, Zürich, New York: Georg Olms.

Hajdeger, Martin (1997), Uvod u metafiziku, preveo V. Đaković, Vrnjačka Banja: Eidos.

Hajdeger, Martin (1998), „Moj put u fenomenologiju“, u: O stvari mišljenja, preveo B. Zec, Beograd: Plato,str. 79-88.

Hajdeger, Martin (2007), Na putu k jeziku, preveo B. Zec, Beograd: Fedon. 
Hegel, Georg Wilhelm Friedrich (1987), Enciklopedija filozofijskih znanosti, preveo V. D. Sonnenfeld, Sarajevo: Veselin Masleša.

Heidegger, Martin (1976), Logik: Die Frage nach der Wahrheit, GA 21, W. Biemel (Hg.), Frankfurt am Main: Vittorio Klostermann.

Heidegger, Martin (1978), Frühe Schriften, GA 01, F.-W. von Herrmann(Hg.), Frankfurt am Main: Vittorio Klostermann.

Heidegger, Martin (1983), Die Grundbegriffe der Metaphysik. Welt - Endlichkeit - Einsamkeit, GA 29/30, F.-W. von Herrmann (Hg.), Frankfurt am Main: Vittorio Klostermann.

Heidegger, Martin (1985), Bitak i vrijeme, preveo H. Šarinić, Zagreb: Naprijed.

Heidegger, Martin (1992), Platon: Sophistes, GA 19, I. Schüßler (Hg.), Frankfurt am Main: Vittorio Klostermann.

Heidegger, Martin (1994), Phänomenologische Interpretationen zu Aristoteles, GA 61,W. Bröcker, K. Bröcker-Oltmanns (Hgs.), Frankfurt am Main:Vittorio Klostermann.

Heidegger, Martin (1999), Zur Bestimmung der Philosophie, GA 56/57, B. Heimbüchel (Hg.), Frankfurt am Main: Vittorio Klostermann.

Heidegger, Martin (2004), Der Begriff der Zeit, GA 64, F.-W. von Herrmann (Hg.), Frankfurt am Main: Vittorio Klostermann.

Heidegger, Martin (2006), Temeljni problemi fenomenologije, preveo Ž. Pavić, Zagreb: Demetra.

Heidegger, Martin i Heinrich Rickert (2002), Briefe 1912 bis 1933, A. Denker (Hg.), Frankfurt am Main: Vittorio Klostermann.

Husserl, Edmund (1970), Philosophie der Arithmetik: Mit Ergänzenden Texten (1890-1901), Den Haag: Martinus Nijhoff.

Husserl, Edmund (2005), Logička istraživanja. Sv. 2; 3, Istraživanja o fenomenologiji i teoriji spoznaje, preveo Ž. Pavić, Zagreb: Naklada Breza.

Jungen, Oliver i Horst Lohnstein (2007), Geschichte der Grammatiktheorie von Dionysios Thrax bis Noam Chomsky, München: Wilhelm Fink.

Lask, Emil (1923), Gesammelte Schriften, Bd. II, Tübingen: J.C.B. Mohr (Paul Siebeck).

Lask, Emil (1991), „Postoji li „primat praktičkog uma“ u logici?“, u: Filozofija prava i kraći spisi, preveo D. Basta, Novi Sad: Izdavačka knjižarnica Zorana Stojanovića, str. 109-119.

Rickert, Heinrich (1915), Der Gegenstand der Erkenntnis: Einführung in die Transzendentalphilosophie, 3. Aufl., Tübingen: J. C. B. Mohr (Paul Siebeck). 
Steinthal, Heymann (1881), Einleitung in die Psychologie und Sprachwissenschaft, Berlin: Harrwitz und Gossmann.

Windelband, Wilhelm (1900), „Vom System der Kategorien“, u: Philosophische Abhandlungen. Christoph Sigwart zu seinem 70. Geburtstage, Tübingen, Freiburg I. B., Leipzig: Mohr, str. 41-58.

Windelband, Wilhelm (1912), „Logik“, u: Die Philosophie im Beginn des zwanzigsten Jahrhunderts. Festschrift für Kuno Fischer, 2. Aufl., W. Windelband (Hg.), Heidelberg: Carl Winter's Universitätsbuchhandlung, str. 183-207.

\title{
BOJAN SRETOVIĆ
}

University of Novi Sad, Faculty of Philosophy

\section{THE PLACE OF GRAMMATICA SPECULATIVA IN HEIDEGGER'S EARLY PHILOSOPHY}

\begin{abstract}
Heidegger's often neglected early work on logic bears traces of what would become his later philosophy's turn to language. Following Husserl's claim in "Logical Investigations" that the existence of a priori laws which determine the possible forms of meaning speaks to the old idea of a universal grammar, Heidegger offered a phenomenological reading of Duns Scotus' De modis significandi. In addition to phenomenology as the dominant strain, Heidegger in his habilitation work attempted to bring together neo-Scholasticism, neoKantism and the philosophy of life. The neo-Kantian preoccupation with the problem of fringe phenomena, such as the impersonal sentence, the question and negative judgment, was of particular significance for Heidegger. While Husserl's idea of pure grammar took precedent over Lask's metagrammatical theory of predication, Lask's presence in Heidegger's early work was immense. His examination of the role of reflexive categories drew Heidegger's attention to the hidden structures in living language upon which philosophical discourse must draw.
\end{abstract}

Keywords: Heidegger, Grammatica speculativa, Husserl, Lask, logic

Primljeno: 9.7.2020.

Prihvaćeno: 1.9 .2020$. 